\title{
Skema Penyembunyian Data pada Gambar Berbasis Interpolasi Kubik B-Spline Menggunakan Metode Least Significant Bit (LSB)
}

\author{
Garno $^{\# 1}$, Riza Ibnu Adam ${ }^{\# 2}$ \\ ${ }^{\#}$ Fakultas Ilmu Komputer, Program Studi Teknik Informatika, Universitas Singaperbangsa Karawang \\ Jl. H.S. Ronggowaluyo, Telukjambe Timur, Karawang 41361 \\ ${ }^{1}$ garnoestaff.unsika.ac.id \\ 2riza.adamestaff.unsika.ac.id
}

\begin{abstract}
Abstrak - Maraknya kasus pencurian data menyebabkan sistem keamanan pesan harus ditingkatkan. Salah satu cara untuk mengamankan pesan adalah dengan memasukkan pesan ke dalam gambar digital. Penelitian ini bertujuan untuk meningkatkan kualitas gambar digital dalam sistem keamanan pesan tersembunyi. Teknik yang digunakan untuk keamanan pesan adalah steganografi. Cover image akan dikonversi menjadi bit piksel dalam domain spasial. Cover image digunakan dalam bentuk gambar digital dengan format .jpg. Teknik meningkatkan kualitas dan kapasitas gambar digital dilakukan dengan menambahkan dan meningkatkan bit piksel menggunakan metode interpolasi Cubik B-Spline. Cover image yang telah di interpolasi, kemudian disisipi pesan menggunakan metode least significant bit (LSB) untuk memperoleh stegoimage. Pesan yang diselipkan berbentuk file .doc, .docx, .pdf, .xls, .rar, .iso dan .zip dengan ukuran berbeda-beda kapasitasnya. Teknik uji dibuat dengan bantuan perangkat lunak MATLAB versi 2017a. Penelitian melakukan uji dengan mengukur nilai kualitas penyamaran dari stegoimage menggunakan Peak Signal to Noise Ratio (PSNR) dengan rata-rata perolehan stegoimage terhadap Original image $29.06 \mathrm{~dB}$ dan stegoimage terhadap Image interpolation $64.34 \mathrm{~dB}$ dan uji mean squared error (MSE) dengan rata-rata perolehan 97.54 dB pada Image interpolation terhadap original image dan $97.55 \mathrm{~dB}$ pada stegoimage terhadap original image, $0.13 \mathrm{~dB}$ nilai MSE stegoimage terhadap Image interpolation. Hasil uji pada penelitian dengan proses interpolasi pada coverimage dengan Cubic B-Spline mempengaruhi terhadap nilai samar atau Nilai PSNR.
\end{abstract}

\section{Kata kunci - Steganography, interpolation, Cubic B-Spline, Stegoimage, Hiding message, Least Significant Bit (LSB), Digital Image.}

\section{Pendahuluan}

Keamanan data menjadi isu penting dalam perkembangan teknologi informasi dan komunikasi saat ini[1-4]. Salah satu teknik yang dapat digunakan dalam komunikasi rahasia, yaitu steganography[5-7]. Teknik yang memanfaatkan media penampung (citra digital) untuk menyembunyikan atau menyelipkan pesan sebenarnya merupakan metode yang digunakan oleh steganography[8][9]. Metode kerja steganography yaitu pesan disisipkan secara acak dalam bentuk bit-bit piksel yang terdapat pada citra digital[10][11]. Penggunaan citra digital sebagai media penampung mempunyai kelebihan karena indera penglihatan manusia memiliki keterbatasan terhadap warna, sehingga sulit membedakan citra digital yang asli dengan citra digital yang telah disisipi pesan yang bersifat rahasia[12][13]. Meskipun begitu, untuk data yang berukuran besar sangat mungkin terjadinya perubahan kualitas citra digital[14][15].

Perubahan kualitas citra terjadi karena proses penyisipan pesan ke dalam media penampung menambahkan/menghapus nilai-nilai frekuensi tinggi. Selain itu, perubahan pada bit-bit terakhir (least significant bit) media penampung harus memiliki kekuatan citra yang sangat dalam. Bahkan perubahan penyesuaian kontras/kecerahan dapat merubah kualitas citra[16]. K.H. Jung dan K.Y.Yoo menunjukkan bahwa interpolasi mampu meningkatkan kualitas citra media penampung sebesar $35 \mathrm{~dB}[17][18]$. Hasil lainnya diperkuat oleh I. Gholampour dan K. Khosravi yang menunjukkan bahwa interpolasi memiliki nilai rata-rata kualitas citra terbaik dibandingkan metode Exploiting Modification Direction (EMD), metode Integrated Encoding dan metode Double Layer Embedding (DLE)[19]. Selain itu, penerapan interpolasi dalam steganography juga memiliki kompleksitas komputasi yang lebih rendah namun tetap memiliki kualitas citra yang baik[20].

Secara umum, peningkatan kualitas dan kapasitas citra digital dapat dilakukan dengan metode interpolasi[21][22] Teknik interpolasi menghasilkan titik-titik data baru dari perhitungan titik-titik yang sudah ada sebelumnya[23][24] Proses peningkatan kualitas citra dilakukan dengan meningkatkan (atau mengurangi) jumlah piksel dari sebuah warna ataupun intensitas[25]. Salah satu metode terbaik dalam pengolahan citra yaitu metode interpolasi Cubic B-Spline, metode ini mampu bekerja 50\% lebih 
baik dibandingkan dengan interpolasi bicubic[26]. Metode interpolasi Cubik B-Spline juga mampu mengatasi permasalahan citra digital seperti penyaringan, ekstraksi fitur, pencocokan, pembelokkan, reduksi, dan pembesaran gambar[27][28].

Berdasarkan uraian tersebut, maka penelitian ini bertujuan untuk menerapkan metode interpolasi $C u b i k B$ Spline atau Kubik B-Spline digunakan untuk interpolasi cover image kemudian hasilnya menjadi image interpolation yang berguna sebagai media penyelipan pesan. Metode least significant bit (LSB) digunakkan untuk menyisipkan pesan kedalam citra digital[29] dan menghasilkan stegoimage. Metode interpolasi Cubik BSpline sebagai proses peningkatan kualitas dan kapasitas citra digital. Penelitian ini, pengukuran nilai kesamaran dan kualitas stegoimage dilakukan dengan mengukur nilai Peak Signal to Noise Ratio (PSNR) dan Mean Squared Error (MSE)[30].

\section{Metodologi Penelitian}

Penelitian dimaksudkan untuk memperoleh nilai perubahan kualitas citra pada media penampung dengan menerapkan metode interpolasi Cubik B-Spline. Adapun tahapan penelitian meliputi persiapan, perancangan program, dan analisa hasil. Keseluruhan tahapan penelitian diperlihatkan dalam bentuk diagram alir pada Gambar 1.

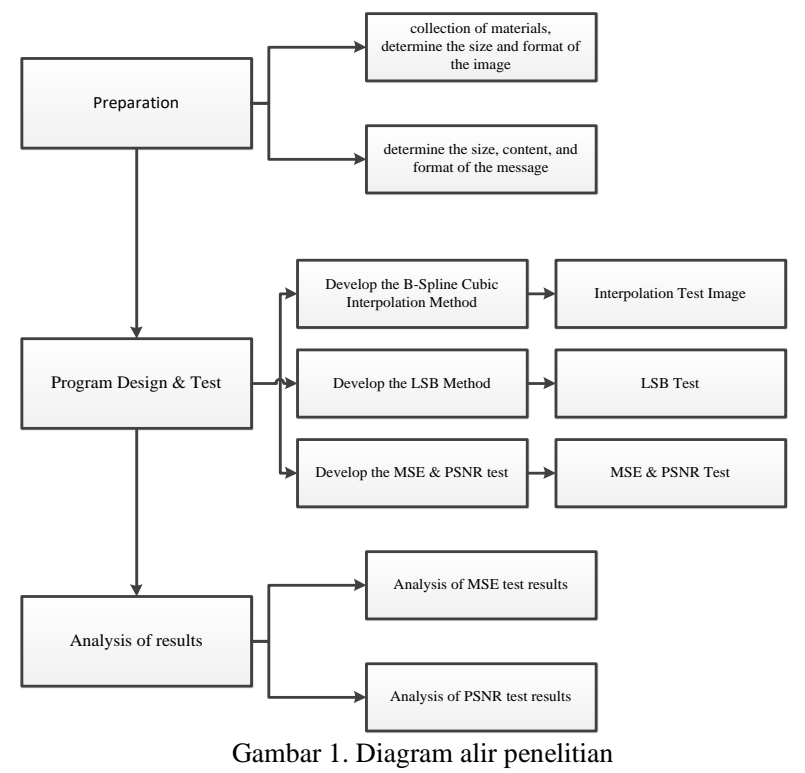

\section{A. Tahap Persiapan}

Media penampung yang digunakan berupa citra digital. Citra digital memiliki format file berupa jpg, dengan ukuran file masing-masing sebesar 46.2 KB Tulips.jpg, 41.7 KB Desert.jpg, 49.0 KB Koala.jpg, $40.8 \mathrm{~KB}$ Penguins.jpg, $37.8 \mathrm{~KB} \quad$ Lighthouse.jpg, 54.5 KB Chrysanthemum.jpg, 277 KB Tiger.jpg dan 44.2 KB Hydrangeas.jpg. Sedangkan untuk pesan yang disisipkan berformat docx, pdf, excel/xls, iso, zip dan rar berukuran masing-masing sebesar $13.4 \mathrm{~KB}$ docx, $172 \mathrm{~KB}$ file excel dan $87.7 \mathrm{~KB}$ file zip, $148 \mathrm{~KB}$ file ISO, 86.8 KB rar, 237 KB file pdf.

\section{B. Perancangan Program}

Pada tahap ini citra digital akan diubah kedalam bit-bit piksel domain spasial. Bit-bit tersebut selanjutnya diolah secara komputasi menggunakan metode interpolasi Cubik $B$-Spline. Hasilnya akan diperoleh citra digital baru yang memiliki kerapatan piksel yang berbeda. Citra digital yang telah di interpolasi kemudian akan disisipi pesan teks. Proses penyisipan pesan dilakukan menggunakan metode LSB. Citra digital yang telah disisipi pesan selanjutnya akan diukur nilai PNSR dan MSE. Proses perancangan program untuk pengujian dilakukan menggunakan software Matlab 2017a. Keseluruhan proses perancangan program diperlihatkan pada Gambar 2.

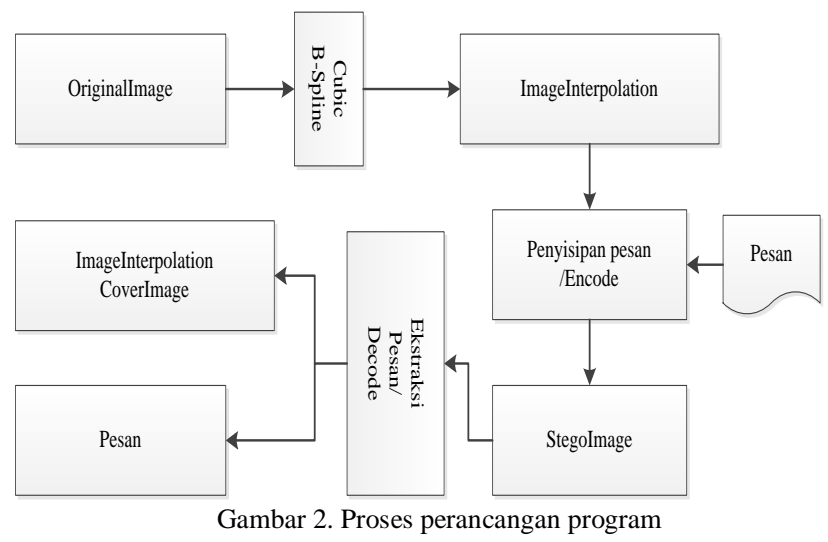

\section{Uji Kualitas Image dan Anilisis Hasil}

Analisis hasil dilakukan dengan cara mengukur nilai PNSR, MSE, pada original image dan citra digital hasil interpolasi mendapatkan rata-rata nilai kemiripan atau PSNR seberapa besar decibel/dBnya, dan mengukur ratarata nilai error atau MSEnya. Berikutnya mengukur hasil stegoimage terhadap original image dengan nilai rata-rata kemiripan dengan original image seberapa besar dBnya, serta nilai errornya atau MSE seberapa dBnya, terakhir mengukur stegoimage yang telah disisipi pesan terhadap imageinterpolasi didapatkan nilai rata-rata PSNR dan MSE seberapa dBnya. Semakin tinggi nilai PNSR, dan semakin kecil MSE maka akan semakin baik kualitas citra digital yang dihasilkan.

\section{HASIL DAN PEMBAHASAN}

Hasil penelitian dari persiapan image yang digunakan sebagai cover image, jenis file pesan yang diselipkan dan hasil uji interpolasi, hasil uji encode berbagai pesan ke dalam image interpolasi serta uji PSNR dan MSE baik pada stegoimage terhadap original image, dan stegoimage terhadap image interpolation. Adapun bahan dan hasil uji dapat dilihat pada tabel.

\section{A. Bahan uji (Originallmage)}

Image yang digunakan untuk pengujian berjenis image 24 bit dan berukuran menyesuaikan besar pesan yang akan 
diselipkan, rata-rata image dengan dimensi 256x256 piksel dan satu image berukuran dimensi $1280 \times 1280$ piksel. Tabel 1 merupakan daftar image yang digunakan sebagai uji image yang akan diproses Cubic B-Spline.

TABEL I

COVER IMAGE/ORIGINAL IMAGE

\begin{tabular}{|c|c|c|c|c|}
\hline No & $\begin{array}{l}\text { Original } \\
\text { image }\end{array}$ & Nama & Dimensi & Size \\
\hline 1. & & $\begin{array}{l}\text { Tulips. } \\
\text { jpg }\end{array}$ & $\begin{array}{l}256 \times 256 \\
p x\end{array}$ & $47 \mathrm{~KB}$ \\
\hline 2. & & $\begin{array}{l}\text { Desert. } \\
\text { jpg }\end{array}$ & $\begin{array}{l}256 \times 256 \\
p x\end{array}$ & $43 \mathrm{~KB}$ \\
\hline 3. & & $\begin{array}{l}\text { Koala. } \\
\text { jpg }\end{array}$ & $\begin{array}{l}256 \times 256 \\
p x\end{array}$ & $43 \mathrm{~KB}$ \\
\hline 4. & & $\begin{array}{l}\text { Penguins } \\
\text {.jpg }\end{array}$ & $\begin{array}{l}256 \times 256 \\
p x\end{array}$ & $42 \mathrm{~KB}$ \\
\hline 5. & & $\begin{array}{l}\text { Lightho } \\
\text { use.jpg }\end{array}$ & $\begin{array}{l}256 \times 256 \\
p x\end{array}$ & $39 \mathrm{~KB}$ \\
\hline 6. & & $\begin{array}{l}\text { Tiger. } \\
\text { jpg }\end{array}$ & $\begin{array}{l}1280 \times 1280 \\
p x\end{array}$ & $233 \mathrm{~KB}$ \\
\hline 7. & & $\begin{array}{l}\text { Chrysan } \\
\text { themum. } \\
\text { jpg }\end{array}$ & $\begin{array}{l}256 \times 256 \\
p x\end{array}$ & $56 \mathrm{~KB}$ \\
\hline 8. & & $\begin{array}{l}\text { Hydran } \\
\text { geas.jpg }\end{array}$ & $\begin{array}{l}256 \times 256 \\
p x\end{array}$ & $45 \mathrm{~KB}$ \\
\hline
\end{tabular}

B. File Pesan untuk diselipkan

File pesan yang digunakan untuk diselipkan terdiri dari berbagai tipe file seperti jenis $d o c x, p d f$, $p d f$ yang berisi text dan gambar, file .zip, file .iso, .rar, .xls, excel yang di kompres .rar, semuanya memiliki ukuran yang berbedabeda seperti pada Tabel 2 .

TABEL II

MACAM-MACAM PESAN YANG DISELIPKAN

\begin{tabular}{|c|c|c|c|}
\hline \multirow[b]{2}{*}{ No } & \multicolumn{3}{|c|}{ Pesan } \\
\hline & $\begin{array}{l}\text { Jenis dan } \\
\text { Nama file }\end{array}$ & Size & Keterangan \\
\hline 1 & Deksfull.docx & $14 \mathrm{~KB}$ & $\begin{array}{l}\text { Pesan isinya } \\
\text { Full Text } \\
\text { berformat docx }\end{array}$ \\
\hline 2 & $\begin{array}{l}\underline{P D F} \\
\text { Teksfull.pdf } \\
\end{array}$ & $86 \mathrm{~KB}$ & $\begin{array}{l}\text { Pesan isinya full } \\
\text { text berformat } \\
\text { pdf }\end{array}$ \\
\hline 3 & 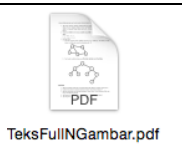 & $33 \mathrm{~KB}$ & $\begin{array}{l}\text { Pesan isinya full } \\
\text { text dan gambar } \\
\text { berformat pdf }\end{array}$ \\
\hline 4 & $\begin{array}{c}\text { ZIP } \\
\text { teksetengah.zip }\end{array}$ & $90 \mathrm{~KB}$ & $\begin{array}{l}\text { Pesan berisi text } \\
\text { full berformat } \\
\text { docx dan pdf } \\
\text { dikompress zip }\end{array}$ \\
\hline 5 & 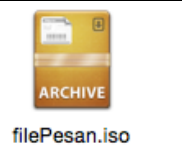 & $152 \mathrm{~KB}$ & $\begin{array}{l}\text { Pesan berisi text } \\
\text { full berformat } \\
\text { docx dan pdf } \\
\text { dikompress iso }\end{array}$ \\
\hline 6 & $\begin{array}{l}\text { Ea } 90 \\
\text { RAR } \\
\text { filePesan.rar }\end{array}$ & $89 \mathrm{~KB}$ & $\begin{array}{l}\text { Pesan berisi text } \\
\text { full berformat } \\
\text { docx dan pdf } \\
\text { dikompress rar }\end{array}$ \\
\hline 7 & $\begin{array}{l}\text { KLLS } \\
\text { KOMMASMHS2014 } \\
\text { UTSUAS...72017.xIS }\end{array}$ & $177 \mathrm{~KB}$ & $\begin{array}{l}\text { Pesan berisi } \\
\text { document excel } \\
\text { berformat exls }\end{array}$ \\
\hline 8 & $\begin{array}{l}\text { RAR } \\
\text { filepesanExcel.rar }\end{array}$ & $73 \mathrm{~KB}$ & $\begin{array}{l}\text { Pesan berisi } \\
\text { document excel } \\
\text { berformat exls } \\
\text { dan dikompress } \\
\text { rar }\end{array}$ \\
\hline
\end{tabular}

\section{Uji Interpolasi}

Pengujian interpolasi terhadap Original image untuk digunakan sebagai cover digunakan untuk penyelipan pesan dilakukan pada gambar berformat jpg, interpolasi menggunakan fungsi Cubic B-Spline terhadap image dengan proses pembesaran sebanyak 1.5 kali atau 2 kali. Adapun hasil uji dapat dilihat pada Tabel 3.

TABEL III

UJI INTERPOLATION KUBIK B-SPLINE IMAGE

\begin{tabular}{|c|c|c|}
\hline No & Original image & Image interpolation \\
\hline 1 & $\begin{array}{l}\text { Tulips.jp } \\
\text { g } 47 \mathrm{~KB}, \\
256 \mathrm{x} \\
256\end{array}$ & $\begin{array}{l}\text { Tulips } \\
\text { inter.jpg } \\
23 \mathrm{~KB}, \\
384 \mathrm{x} \\
384\end{array}$ \\
\hline
\end{tabular}




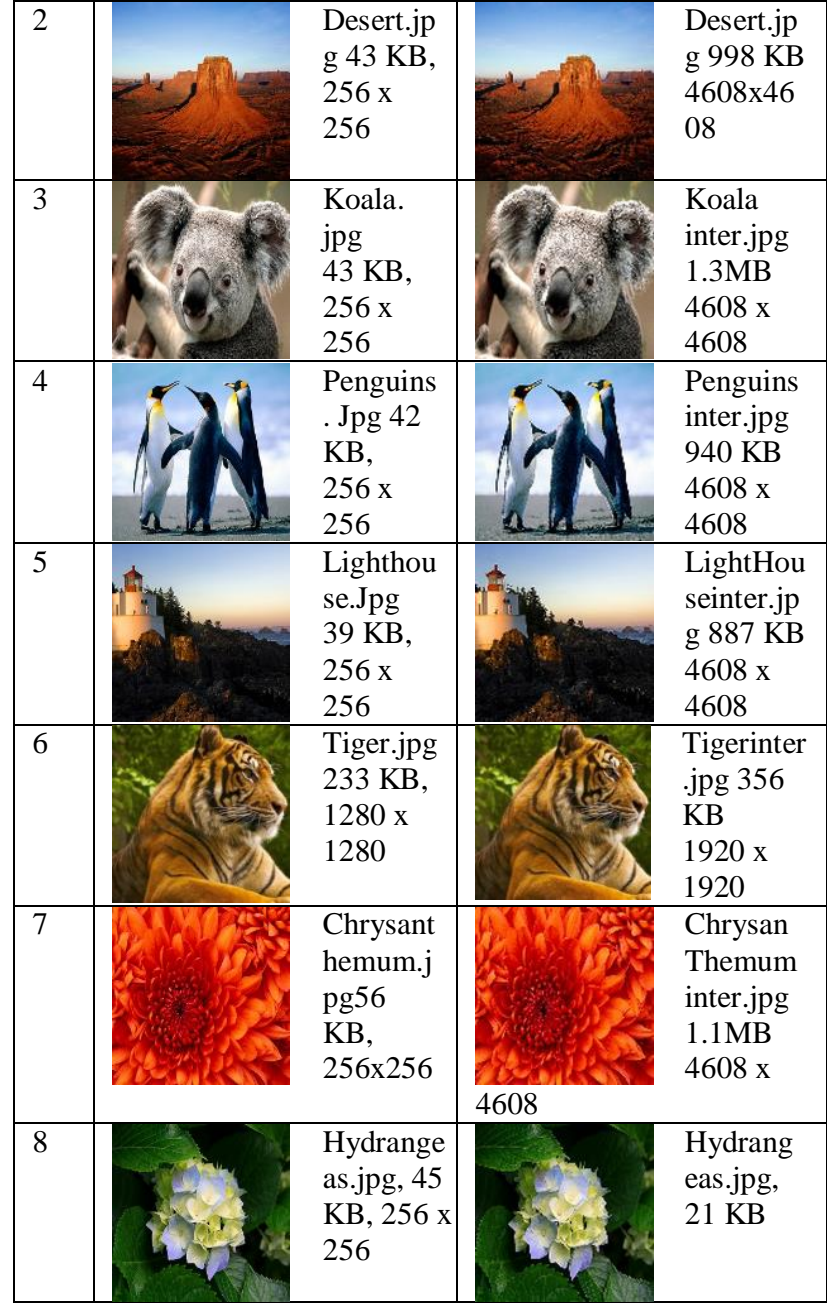

\section{Uji Penyelipan Pesan dengan LSB (Encode)}

Penyelipan pesan dengan berbagai jenis file di encode ke dalam Image interpolation dan menghasilkan stegoimage. Adapun hasil uji yang diperoleh dapat dilihat pada Tabel 4.

TABEL IV

UJI EMBED PESAN DENGAN LSB

\begin{tabular}{|c|c|c|c|}
\hline No & $\begin{array}{l}\text { Image Inte } \\
\text { rpolation }\end{array}$ & Pesan & Stegoimage \\
\hline 1 & $\begin{array}{l}\text { ond I } \\
\text { Tulipsinter. } \\
\text { jpg, } 23 \mathrm{~KB} \text {, } \\
384 \text { x } 384 \text { px }\end{array}$ & $\begin{array}{l}\text { Docx } \\
\text { Tekstull.docx } \\
14 \mathrm{~KB} \text {, Pesan } \\
\text { isinya Full } \\
\text { Textber } \\
\text { format docx. }\end{array}$ & $\begin{array}{l}\text { stef } \\
\text { Stego } \\
\text { imageTextfull } \\
\text {.jpg, } 23 \mathrm{~KB} 384 \\
\mathrm{x} 384\end{array}$ \\
\hline 2 & $\begin{array}{l}\text { Desertinter.jpg, } \\
998 \mathrm{~KB}, 4608 \\
\text { x } 4608\end{array}$ & $\begin{array}{l}\text { PDF } \\
\text { Teksfull.pdf } \\
86 \mathrm{~KB} \text {, Pesan } \\
\text { isinya Full Text } \\
\text { berformat pdf. }\end{array}$ & $\begin{array}{l}\text { Stegoimage } \\
\text { Textfullpd } \\
\text { f.Jpg, } 997 \mathrm{~KB} \text {, } \\
4608 \times 4608\end{array}$ \\
\hline
\end{tabular}

\begin{tabular}{|c|c|c|c|}
\hline 3 & $\begin{array}{l}\text { Koalainter.jpg } \\
1.3 \mathrm{MB} \\
4608 \text { x } 4608\end{array}$ & $\begin{array}{l}\text { TeksFulingambar.pdf } \\
33 \mathrm{~KB} \text {,Pesan } \\
\text { isinya full text } \\
\text { dan gambar } \\
\text { berformat pdf. }\end{array}$ & $\begin{array}{l}\text { Stegoimage } \\
\text { TextfullNGa } \\
\text { Mbarpdf.jpg } 1.3 \\
\text { MB,4608x } 4608\end{array}$ \\
\hline 4 & 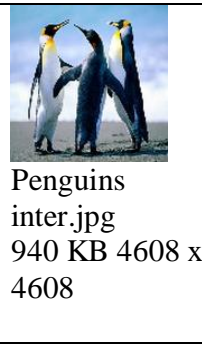 & $\begin{array}{l}\text { (1) } \\
\text { zIP } \\
\text { teksetengah.zip } \\
90 \mathrm{~KB} \text {, Pesan } \\
\text { berisi text full } \\
\text { berformat docx } \\
\text { dan pdf } \\
\text { dikompress zip. }\end{array}$ & $\begin{array}{l}1.1 D \\
\text { Stegoimage } \\
\text { TextSeteng } \\
\text { ahZip.jpg } \\
940 \mathrm{~KB} \text {, } \\
4608 \text { x } 4608\end{array}$ \\
\hline 5 & $\begin{array}{l}\text { Lighthouse } \\
\text { inter.jpg } 887 \\
\text { KB } 4608 \text { x } \\
4608\end{array}$ & $\begin{array}{l}\text { ARchive } \\
\text { filePesan.iso } \\
152 \mathrm{~KB} \text {, Pesan } \\
\text { berisi text full } \\
\text { berformat docx } \\
\text { dan pdf } \\
\text { dikompress iso. }\end{array}$ & $\begin{array}{l}\text { Stegoimage } \\
\text { filePesan } \\
\text { ISO.jpg, } \\
887 \mathrm{~KB}, \\
4608 \times 4608\end{array}$ \\
\hline 6 & $\begin{array}{l}\text { Tigerinter.jpg } \\
356 \text { KB } 1920 \\
\text { x } 1920\end{array}$ & $\begin{array}{l}\text { RAR } \\
\text { filePesan.rar } \\
89 \mathrm{~KB} \text {, Pesan } \\
\text { berisi text } \\
\text { fullberformat } \\
\text { docx dan pdf } \\
\text { dikompress rar }\end{array}$ & $\begin{array}{l}\text { Stegoimagefile } \\
\text { Pesanrar.jpg } \\
\text { 356 KB } \\
\text { 1920x1920 }\end{array}$ \\
\hline 7 & $\begin{array}{l}\text { } \\
\text { Chrysanthe } \\
\text { muminter.Jpg } \\
1.1 \mathrm{MB} \\
4608 \times 4608\end{array}$ & $\begin{array}{l}\text { ExLS } \\
\text { KOMMASMHS2014 } \\
\text { UTSUAS...72017.xls } \\
177 \mathrm{~KB}, \text { Pesan } \\
\text { berisi document } \\
\text { excel berformat } \\
\text { exls. }\end{array}$ & $\begin{array}{l}\text { ond } \\
\text { Stegoimagefile } \\
\text { Pesanexcel.jpg } \\
1.1 \mathrm{MB} 4608 \mathrm{x} \\
4608\end{array}$ \\
\hline 8 & $\begin{array}{l}\text { Hydrangeas } \\
\text { inter.jpg } 21 \\
\text { KB } 384 \text { x } 384\end{array}$ & $\begin{array}{l} \\
\text { RAR } \\
\text { filepesanExcel.rar } \\
73 \text { bytes, Pesan } \\
\text { berisi document } \\
\text { berformat exls } \\
\text { dan dikompress } \\
\text { rar }\end{array}$ & $\begin{array}{l}\text { Stegoimage } \\
\text { filePesanex } \\
\text { celrar.jpg } 21 \\
\text { KB, 384x384 }\end{array}$ \\
\hline
\end{tabular}

\section{E. Uji Kualitas Image}

Pengujian kualitas image yang dilakukan dengan menguji PSNR dan MSE terhadap original image dengan Image interpolasition dan stegoimage, Image interpolation dengan stegoimage.

\section{Uji Peak Signal-to-Noise Ratio (PSNR)}

Uji kualitas image (Peak Signal-to-Noise Ratio) PSNR yang dilakukan dengan membandingkan antara hasil 
Image interpolation terhadap Original image, stegoimage terhadap Original image serta stegoimage terhadap Image interpolation. Adapun hasil uji dapat dilihat pada Tabel 5 .

TABEL V

HASIL UJI PEAK SIGNAL-TO-NOISE RATIO (PSNR)

\begin{tabular}{|l|l|l|l|l|}
\hline \multirow{2}{*}{ No } & \multirow{2}{*}{$\begin{array}{c}\text { Original } \\
\text { Image } \\
\text { name }\end{array}$} & \multirow{2}{*}{$\begin{array}{c}\text { Image } \\
\text { Inter } \\
\text { polation } \\
(\mathbf{d B})\end{array}$} & $\begin{array}{l}\text { to } \\
\text { Original } \\
\text { image } \\
(\mathbf{d B})\end{array}$ & $\begin{array}{l}\text { Stegoimage } \\
\text { Inter } \\
\text { polation } \\
\text { (dB) }\end{array}$ \\
\hline 1 & Tulips.jpg & 30.15 & 30.14 & 49.15 \\
\hline 2 & Desert.jpg & 27.02 & 27.02 & 68.53 \\
\hline 3 & Koala.jpg & 27.14 & 27.14 & 69.67 \\
\hline 4 & $\begin{array}{l}\text { Ping } \\
\text { uins.jpg }\end{array}$ & 25.95 & 25.95 & 65.55 \\
\hline 5 & $\begin{array}{l}\text { Light } \\
\text { house.jpg }\end{array}$ & 27.90 & 27.90 & 68.06 \\
\hline 6 & Tiger.jpg & 28.92 & 28.92 & 74.66 \\
\hline 7 & $\begin{array}{l}\text { Chrysan } \\
\text { Them } \\
\text { um.jpg }\end{array}$ & 37.06 & 37.06 & 61.56 \\
\hline 8 & $\begin{array}{l}\text { Hydra } \\
\text { ngeas.jpg }\end{array}$ & 28.32 & 28.33 & 57.37 \\
\hline
\end{tabular}

Perolehan hasil pengujian Peak Signal-to-Noise Ratio (PSNR) yang semula diharapkan bahwa semakin besar PSNR maka semakin baik stegoimage yang dihasilkan. Beberapa nilai yang didapatkan yaitu pengujian PSNR antara Image interpolation terhadap Original image didapatkan rata-rata $29.06 \mathrm{~dB}$, PSNR Stegoimage terhadap Original image mendapatkan rata-rata 29.06 $\mathrm{dB}$, tetapi PSNR stegoimage terhadap Image interpolation mendapatkan rata-rata $64.34 \mathrm{~dB}$.

\section{Uji Mean Squared Error (MSE)}

Uji kualitas image mean squared error (MSE) yang dilakukan dengan membandingkan antara hasil Image interpolation terhadap Original image, stegoimage terhadap Original image serta stegoimage terhadap Image interpolation. Adapun hasil uji yang diperoleh dapat dilihat pada Tabel 6.

TABEL VI

HASIL UJI MEAN SQUARED ERROR (MSE)

\begin{tabular}{|l|l|l|l|l|}
\hline \multirow{2}{*}{ No } & \multirow{2}{*}{$\begin{array}{c}\text { Original } \\
\text { image } \\
\text { name }\end{array}$} & \multirow{2}{*}{$\begin{array}{c}\text { Image } \\
\text { Inter } \\
\text { polation } \\
(\mathbf{d B})\end{array}$} & $\begin{array}{l}\text { 㞷o } \\
\text { Original } \\
\text { image } \\
\text { (dB) }\end{array}$ & $\begin{array}{l}\text { to Image } \\
\text { Inter } \\
\text { polation } \\
\text { (dB) }\end{array}$ \\
\hline 1 & Tulips.jpg & 62.84 & 62.98 & 0.7908 \\
\hline 2 & Desert.jpg & 129.25 & 129.25 & 0.0091 \\
\hline 3 & Koala.jpg & 125.73 & 125.72 & 0.0070 \\
\hline 4 & $\begin{array}{l}\text { Ping } \\
\text { uins.jpg }\end{array}$ & 165.12 & 165.11 & 0.0181 \\
\hline 5 & $\begin{array}{l}\text { Light } \\
\text { house.jpg }\end{array}$ & 105.49 & 105.49 & 0.0102 \\
\hline 6 & Tiger.jpg & 83.42 & 83.42 & 0.0022 \\
\hline
\end{tabular}

\begin{tabular}{|l|l|l|l|l|}
\hline 7 & $\begin{array}{l}\text { Chrysan } \\
\text { Them } \\
\text { um.jpg }\end{array}$ & 12.80 & 12.81 & 0.0454 \\
\hline 8 & $\begin{array}{l}\text { Hydra } \\
\text { ngeas.jpg }\end{array}$ & 95.64 & 95.62 & 0.1192 \\
\hline
\end{tabular}

Hasil pengujian dari Mean Squared Error (MSE) Image interpolasi terhadap Original image mendapatkan ratarata $97.54 \mathrm{~dB}$, stegoimage terhadap Original image mendapatkan MSE rata-rata $97.55 \mathrm{~dB}$, serta stegoimage terhadap Image interpolation mendapatkan nilai ratarata MSE $0.13 \mathrm{~dB}$.

\section{Pembahasan Analisis hasil}

Setiap pengujian dari awal sampai akhir penggunaan cover image berformat jpg dimaksudkan format tersebut paling banyak dipergunakan oleh rata-rata pengguna perangkat digital. Hasil pengujian Image interpolasi memiliki rata-rata PSNR terhadap Original image 29.06 $\mathrm{dB}$ yang artinya tingkat kemiripan image hasil interpolasi terhadap Original image memiliki nilai kurang baik. Penyebabnya berdasarkan beberapa literatur bahwa PSNR yang baik jika nilainya minimal $40 \mathrm{~dB}$, jika nilai dalam skala logaritmik nilai decibel $\mathrm{dB}$ nilai PSNR jatuh di bawah $30 \mathrm{~dB}$ alasanya bahwa kualitas stegoimage mengindikasikan relative rendah, karena distorsi penyisipan pesan terlihat kasat mata[31][32]. Perbedaan yang sangat jauh ini disebabkan karena adanya proses pembesaran image secara 2 kali lipat dan dimensi dari Original image dan Image interpolation yang berbeda. Uji PSNR stegoimage hasil dari penyisipan pesan berupa file doc, docx, pdf, rar, iso, zip, excel dan berukuran berbedabeda terhadap original image memiliki hasil nilai ratarata $29.06 \mathrm{~dB}$. Berbeda jauh dengan PSNR pada stegoimage terhadap Image interpolation mendapatkan nilai rata-rata PSNR $64.34 \mathrm{~dB}$ artinya sangat baik, hal ini disebabkan karena rata-rat secara dimensi dari Image interpolasi dan stegoimage sama. Artinya PSNR salah satunya dipengaruhi oleh dimensi image.

Uji mean squared error (MSE) pada Image interpolasi terhadap Original image mendapatkan rata-rata 97.54 $\mathrm{dB}$ dan $97.55 \mathrm{~dB}$ pada stegoimage hasil penyisipan pesan berupa file doc, docx, zip, rar, pdf, iso dan excel terhadap Original image, artinya hasil MSE yang ada sangat tidak baik, dengan tingkat error sangat tinggi. Hal ini disebabkan karena efek dari dimensi yang jauh berbeda dan menyebabkan tingkat blur yang terlihat. Berbeda jauh jika dibandingkan dengan hasil uji MSE pada stegoimage terhadap Image interpolation yaitu mendapatkan hasil rata-rata MSE $0.13 \mathrm{~dB}$ sangat baik, alasannya sama yaitu banyak dari sample uji karena memiliki dimensi yang sama saat di uji. Berarti nilai pengujian MSE juga dipengaruhi oleh dimensi dari image uji.

\section{KESIMPULAN}

Penyelipan pesan dengan istilah steganografi dengan preparation proses pada original image untuk 
mendapatkan kemampuan daya tampung yang besar dengan cara interpolasi Cubic B-Spline mempengaruhi hasil kualitas stegoimage yang terjadi. Rata-rata dari hasil stegoimage yang didapatkan nilai PSNR tingkat kemiripan stegoimage terhadap Original image sangat rendah yaitu dibawah $30 \mathrm{~dB}$, begitu juga dengan uji MSE dengan hasil tingkat error yang sangat tinggi. Hasil uji atau stegoimage yang diperoleh artinya memiliki kondisi secara kasat mata terlihat perbedaannya. Penyebab ini semua karena adanya pembesaran terhadap Original image. Pembesaran mengakibatkan dimensi keduanya berbeda jauh.

Sebagai saran model interpolasi Cubic B-Spline yang digunakan untuk untuk zooming image pada teknik steganografi sebaiknya dilakukan proses perbaikan image dengan teknik atau algoritma tertentu agar mendapatkan kualitas stegoimage yang baik dan memiliki nilai PSNR yang tinggi dan MSE yang sangat kecil.

\section{REFERENSI}

[1] L. Rahmi and G. T. Nugroho, "Kebijakan informasi," Shaut alMaktabah J. Perpustakaan,Arsip dan Dokumentasi, vol. 8, no. 2 pp. 155-168, 2011

[2] F. P. Nugroho, R. W. Abdullah, S. Wulandari, and Hanafi, "Keamanan big data di era digital di indonesia," J. Inf. Politek Indonusa Surakarta, vol. 5, no. 1, 2019.

[3] B. Anwar, N. B. Nugroho, J. Prayudha, and A. Azanuddin, "Implementasi Algoritma RSA Terhadap Keamanan Data Simpan Pinjam," J. SAINTIKOM (Jurnal Sains Manaj. Inform. dan Komputer), vol. 18, no. 1, pp. 30-34, 2019.

[4] H. N. Saputra and Jamroni, “Analisis Keamanan Data Sistem Informasi Di Puskesmas Pleret Bantul Yogyakarta," J. Ilm. ILMU KEPERAWATAN DAN ILMU Kesehat. Masy., vol. 12, no. 2, pp. 96-105, 2017.

[5] jhoni V. Purba, M. Situmorang, and D. Arisandi, "Implementasi Steganografi Pesan Text Ke Dalam File Sound (.wav) Dengan Modifikasi jarak Byte Pada Algoritma Least Significant Bit (LSB)," J. Dunia Teknol. Inf., vol. 1, no. 1, pp. 50-55, 2012.

[6] M. F. Syawal, D. C. Fikriansyah, and N. Agani, "Implementasi Teknik Steganografi Menggunakan Algoritma Vigenere Cipher Dan Metode LSB," J. TICOM, vol. 4, no. 3, 2016.

[7] A. F. Aziza and E. M. Imah, "Studi Steganografi Pada Citra Digital Menggunakan Shuffled Singular Value Decomposition (SSVD)," J. Math. Its Appl., vol. 16, no. 1, pp. 1-10, 2019.

[8] M. Azlansyah and B. Setiyono, "Penyisipan Pesan pada Citra Digital Menggunakan Metode Least Significant Bit," J. Sains dan Seni ITS, vol. 8, no. 1, 2019.

[9] S. A. Meliala, "Perancangan Aplikasi Pengkodean dan Penyembunyian Pesan dalam Media Citra dengan Menggunakan Algoritma Atbash Chiper dan Metode Bit Plane Complexity Segmentation," J. Pelita Inform., vol. 18, no. 1, pp. 113-120, 2019.

[10] A. Hafiz, "Steganografi Berbasis Citra Digital Untuk Menyembunyikan Data Menggunakan Metode Least Significant Bit (Lsb)," J. Cendikia, vol. 17, no. 1 April, pp. 194-198, 2019.

[11] M. Syahril and H. Jaya, "Aplikasi Steganografi Pengamanan Data Nasabah di Standard Chartered Bank Menggunakan Metode Least Significant Bit dan RC4,” Semin. Nas. Sains Teknol. Inf., pp. 505$509,2019$.

[12] Apriza, I. I. Tritoasmoro, and N. A. Ramatryana, "Deteksi Posisi Pesan Rahasia Pada Steganografi Citra Berbasis Analisis Raw Quick Pair ( Rqp ) Dan Discrete Wavelet Transform ( DWT ), $e$ Proceeding Eng., vol. 6, no. 1, pp. 616-625, 2019.

[13] S. Lutfi and Rosihan, "Perbandingan Metode Steganografi LSB
(Least Significant Bit) Dan MSB (Most Significant Bit) Untuk Menyembunyikan Informasi Rahasia Kedalam Citra Digital," JIKO (JurnalInformatika dan Komputer) Ternate, vol. 2, no. 1, pp 34-42, 2018.

[14] D. B. Leksono, I. J. Raharjo, I. Safitri, and M. Sc, "Analisis Compressive Sampling Menggunakan Teknik Gabungan SWTDST pada Steganografi Citra Digital Berbasis QIM," eProceeding ofEngineering, vol. 6, no. 1, pp. 249-255, 2019.

[15] S. Nur'aini, "Steganografi Pada Digital Image Menggunakan Metode Least Significant Bit Insertion," Walisongo J. Inf. Technol., vol. 1, no. 1, pp. 73-87, 2019.

[16] T. N. Turnip, J. Doloksaribu, V. Purba, and I. Saragih, "Pengaruh Kapasitas Dimensi Citra Watermark terhadap Audio Watermarking dengan Perpaduan Metode DWT (Discrete Wavelet Transform) dan SVD ( Singular Value Decomposition)," J. Teknol. Inf. dan Ilmu Komput., vol. 6, no. 2, p. 141, 2019.

[17] K. Jung and K. Yoo, "Steganographic method based on interpolation and LSB substitution of digital images," 2014

[18] K. H. Jung and K. Y. Yoo, "Data hiding method using image interpolation," Comput. Stand. Interfaces, vol. 31, no. 2, pp. 465 470, 2009.

[19] I. Gholampour and K. Khosravi, "Interpolation of steganographic schemes," Signal Processing, vol. 98, pp. 23-36, 2014.

[20] M. Tang, S. Zeng, X. Chen, J. Hu, and Y. Du, "An adaptive image steganography using AMBTC compression and interpolation technique," Optik (Stuttg)., vol. 127, no. 1, pp. 471-477, 2016.

[21] J. Sanubari, R. Christanto, J. Sanubari, I. K. Timotius, and I. Bilinear, "Peningkatan Resolusi Citra Digital dengan Interpolasi Bilinear," Techne'Jurnal Ilm. Elektron., vol. 5, no. 1, pp. 1-8, 2006

[22] N. M. Abdi and S. Aisyah, "Peningkatan Kualitas Citra Digital Menggunakan Metode Super Resolusi Pada Domain Spasial," J. Rekayasa Elektr., vol. 9, no. 3, pp. 137-142, 2011.

[23] J. Shi and S. E. Reichenbach, "Image interpolation by twodimensional parametric cubic convolution," IEEE Trans. Image Process., vol. 15, no. 7, pp. 1857-1870, 2006.

[24] I. H. Amin, V. Lusiana, and B. Hartono, "Pencarian Lintasan pada Collision Detection Menggunakan Pendekatan Interpolasi Linier," Pros. SINTAK 2018, pp. 57-61, 2018.

[25] C. Darujati, S. Anam, H. D. Cahyono, and A. B. Gumelar, "Magnifikasi Perbaikan Citra Dijital Multi Resolusi dengan Metode Gabungan Tapis Lolos Bawah dan Interpolasi Bilinear," J. Ilm. Mikrotek, vol. 1, no. 2, 2014.

[26] Z. Pan, W. Chen, Z. Jiang, L. Tang, Y. Liu, and Z. Liu, "Performance of global look-up table strategy in digital image correlation with cubic B-spline interpolation and bicubic interpolation," Theor. Appl. Mech. Lett., pp. 3-7, 2016.

[27] M. Abbas, A. Abd, and J. Ali, "Positivity-preserving rational bicubic spline interpolation for 3D positive data," Appl. Math. Comput., vol. 234, pp. 460-476, 2014.

[28] M. Wulandari, "Pengukuran ssim dan analisis kinerja metode interpolasi untuk peningkatan kualitas citra digital," J. Muara, vol. 1, no. 1, pp. 184-195, 2017.

[29] R. Zaheer, R. S. Gaur, and V. Dixit, "A Literature Survey on Various Approaches of Data hiding in Images," Int. Conf. Innov. Inf. Embed. Commun. Syst., 2017.

[30] S. Hemalatha, U. D. Acharya, and A. Renuka, "Wavelet transform based steganography technique to hide audio signals in image .," Procedia - Procedia Comput. Sci., vol. 47, pp. 272-281, 2015.

[31] A. Cheddad, J. Condell, K. Curran, and P. Mc Kevitt, "Digital image steganography: Survey and analysis of current methods," Signal Processing, vol. 90, no. 3, pp. 727-752, 2010.

[32] A. Solichin, "Mengukur Kualitas Citra Hasil Steganografi," Mengukur Kualitas Citra Has. Steganografi, no. April, pp. 1-4, 2015 